\title{
Incorporation of the Method of Ranking the Hazards of Abandoned Mine Entries into a Rule-Based Expert System
}

\author{
Sphiwe Emmanuel Mhlongo ${ }^{1, *(1)}$, Francis Amponsah-Dacosta ${ }^{1}$ and Armstrong Kadyamatimba ${ }^{2}$ \\ 1 Department of Mining and Environmental Geology, School of Environmental Sciences, University of Venda, \\ Thohoyandou 0950, South Africa; francis.dacosta@univen.ac.za \\ 2 Department of Business Information System, School of Management Sciences, University of Venda, \\ Thohoyandou 0950, South Africa; armstrong.kadyamatimba@univen.ac.za \\ * Correspondence: emmanuel.mhlongo@univen.ac.za; Tel.: +27-159-628-576
}

Received: 20 August 2019; Accepted: 12 September 2019; Published: 30 September 2019

\begin{abstract}
The work of quantifying the problems of abandoned mines is the first step towards the rehabilitation of these mines. As the result, in all countries that have many abandoned mines, researchers and different organizations have been making efforts to develop decision-making tools, methods, and techniques for rehabilitation of abandoned mines. This paper describes the work conducted to incorporate the method for ranking the problems of abandoned mine entries into a rule-based expert system. This is done using the web-based expert system platform provided by expert system (ES)-Builder Shell. The ES is tested by applying it to the case study of the problems of abandoned mine entries in the areas of Giyani and Musina, Limpopo Province of South Africa. This paper gives details of the procedure followed in creating the production rules of the ES for ranking problems of abandoned mine entries (ES-RAME), its attributes, and the results of its application to the selected case study. The use of the ES-RAME is found to be important for setting the objectives and priorities of the rehabilitation of abandoned mine entries. In addition, the incorporation of the ranking method into the expert system ensured that the procedure of the tanking method is clearly communicated and preserved as the rules of the ES. The expert system also has the advantages of being consistent in its guidance, and it gives the user an opportunity to go through the ranking process of the system using any possible fictitious information; this gives the user a feel for the ranking process and the data required when using the ES-RAME.
\end{abstract}

Keywords: abandoned mines; mine entries; expert system; hazard ranking

\section{Introduction}

An expert system (ES) is a computer program that deals with decision making in a specific field of knowledge [1]. It is a branch of artificial intelligence (AI) that uses knowledge and inference procedures to solve problems that generally require human expertise [2]. Expert systems mimic the behavior of human experts [3]. They can be created from information gathered from experts or using model-based information [4]. According to Lucus [5], the term expert system was coined based on the fact that these systems were developed with collaboration with experts during the early days. Currently, shells are used to create an expert system. The expert system shell is basically a computer program that, when supplied with a knowledge base, yields an expert system. It reasons with the knowledge in the knowledge base to produce conclusions that are based on entered facts, which seriously reduces the amount of time and labor required for creation of an expert systems. In general, the shells eliminate the need for programming the rules of the expert system using programming languages such as $\mathrm{C} / \mathrm{C}++$ 
and Cobal [6]. Some of the common expert system shells includes the Art Enterprise, EXSYS CORVID, MP2, Clips, ES-Builder, JESS, AION-DS, EMYCIN, MYCIN, and PROLOG [5,7].

The application of the method for ranking the hazards of abandoned mine shafts into the expert system reported in this paper is achieved by using an ES-Builder Shell@ 2013 McGoo Software. This shell has the advantages of being user friendly, motivating, and compatible with Microsoft Windows [8]. Like other web-based expert system shells, the ES-Builder is commonly used to design expert systems that are accessible as web pages and can be easily incorporated as a knowledge base in the web page [9]. In general, the development of the expert system using the internet technology makes the design and accessibility of the ES easy [10]. The factors that make the internet the best platform for expert system delivery were identified by Grove [11] to be that (i) the internet is readily available, (ii) web-browsers provide a common multimedia interface, (iii) several internet portable tools for knowledge-based systems development are available, (iv) internet-based applications are inherently portable, and (v) emerging protocols support co-operation among knowledge-based systems [12].

\section{The Description of the Problems of Abandoned Mines and the Case Study}

In South Africa, abandoned mines are referred to as those mines for which a closure certificate has not been issued and no party can be traced to assume responsibility for their liabilities; as a result, the funds for their rehabilitation are provided by the government $[13,14]$. Abandoned mines are also considered a costly legacy of previous mining operations that were conducted with no regard for the environment and its protection. Generally, they are found in all countries and/or regions that have a long history of mining. Moreover, they are known for their physical and environmental hazards, which are associated with a magnitude of socio-economic issues. In general, the work of addressing the problems of abandoned mines is concerned with making decisions on which areas to rehabilitate first or which strategies or approaches to use in the rehabilitation work. In view of this, there has been an increase in the amount of research work aimed at developing tools, methods, and/or techniques for the prioritization of the rehabilitation of abandoned mines throughout the world. Some of the published commonly used methods for the prioritization of the rehabilitation of abandoned mines are shown in Table 1 [15]. This paper presents the work conducted with the purpose of implementing the method for ranking the problems of abandoned mines in the rule-based expert system. Such a system has been tested by applying it to the situation of abandoned mine entries in the Giyani and Musina areas, Limpopo Province of South Africa.

The areas of Giyani and Musina are characterized by several abandoned underground gold and copper mines. As a result, the landscapes of these historic mining areas have different features, including the mine entries or shafts that were treated using different methods and materials. These entries or shafts present different physical and environmental hazards. Some of the mine entries in the study areas have never been treated, while treatment or structures used to close some of them have been removed or destroyed by the illegal artisanal miners operating at these sites [16]. The methods used to treat the mine entries in order to reduce or eliminate their physical and environmental hazards include concrete slabs, concrete plugs, a combination of slabs and steel wire screens, heavy steel grate, and steel wire screens. The current state and use of these strategies are summarized in Table 2 [17]. The location of the shafts in the study area is shown in Figure 1. 
Table 1. Description of the popular ranking systems for abandoned mine sites [15].

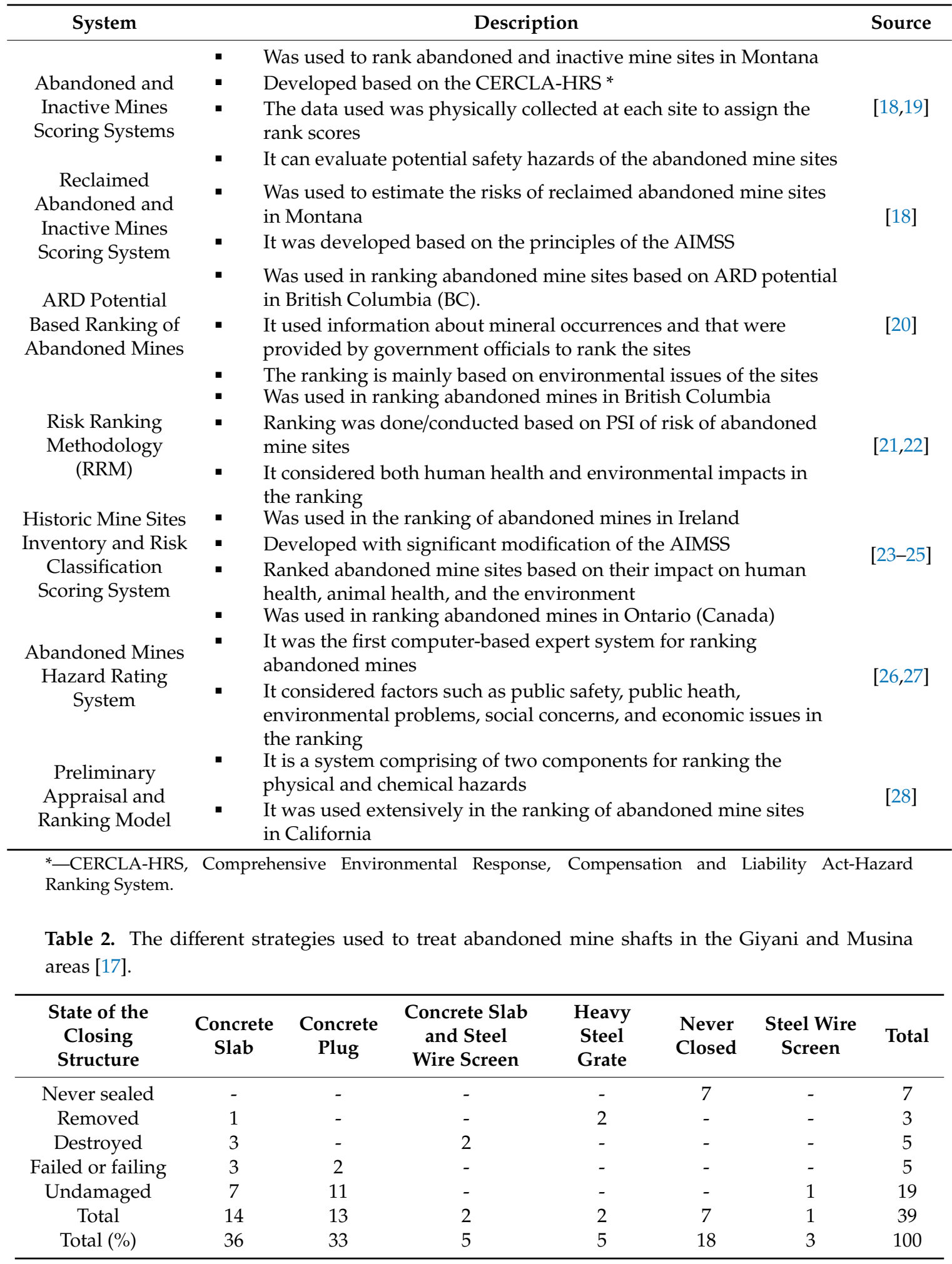

Note: - the issue not applicable. 


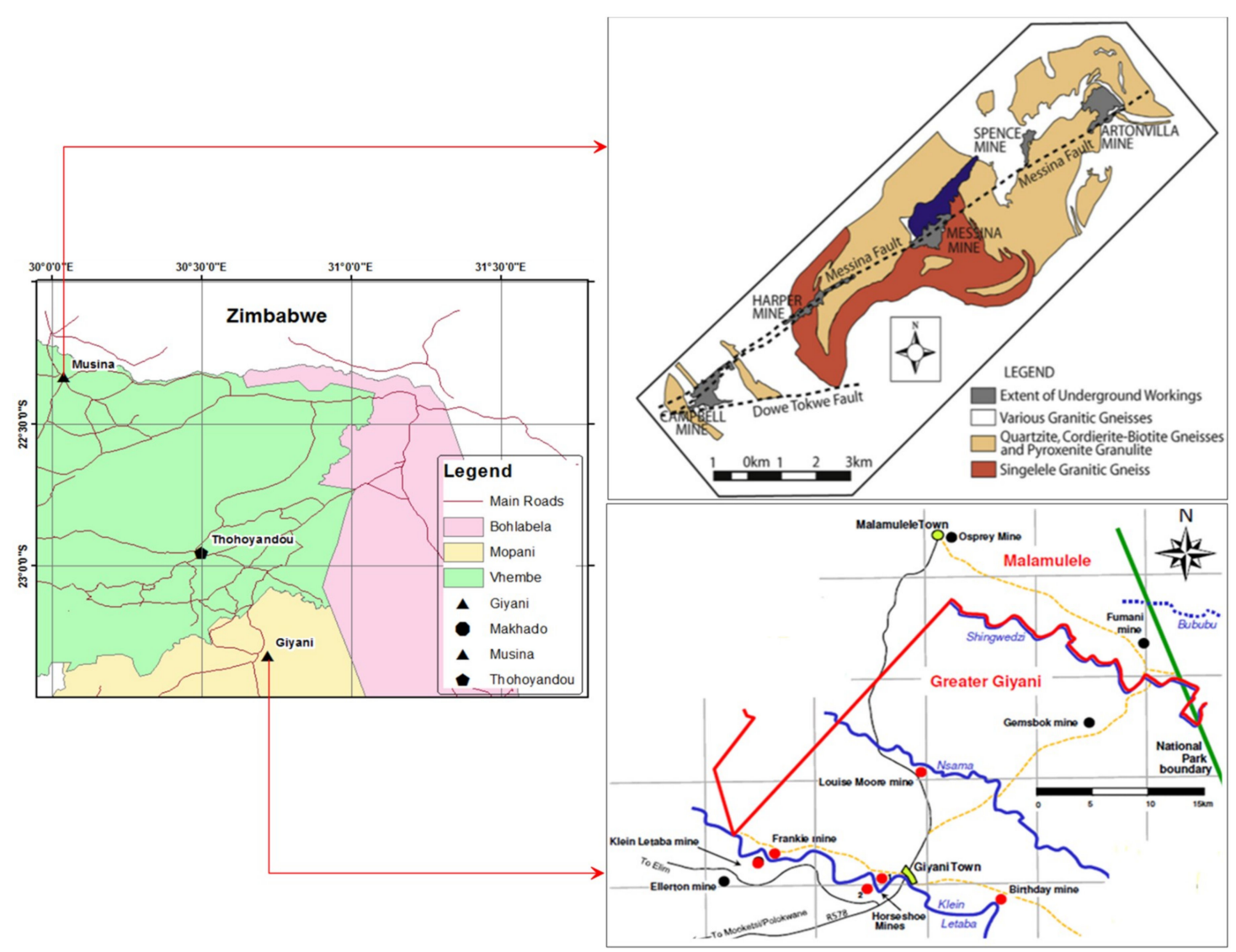

Figure 1. The location of abandoned mine sites in the Giyani and Musina areas $[17,29,30]$.

\section{Methodology}

The development of the expert system for ranking the problems of abandoned mine entries (ES-RAME) began with the acquisition of actual knowledge about the problems of the mine entries. This information was collected through intensive review of literature and field characterization of the mine entries in the study area. This knowledge was used in creating the production rules and the knowledge base of the ES-RAME. These rules were developed based on the procedures of the method for ranking the problems of abandoned mine entries developed by [14]. The rules and the knowledge base of the ES-RAME were created in the ES-Builder Shell@2013 McGoo Software (ES Builder 3.0, McGoo Software, Philippines) through the development of the decision tree of the expert system. According to Zuhra et al. [8], the decision tree is basically a graphical depiction of the knowledge and production rules. In this work, the decision tree was developed by entering the Attributes, Values, and Conclusions in the decision tree model provided by the ES-Builder Shell. The tree was created to have nodes that twigged to other nodes until the conclusion was reached or until the tree was complete. The basic rules that need to be followed when formulating an acceptable decision tree in the ES Builder Shall were satisfied [9]. These rules are summarized and presented in Table 3.

The use of the ES-RAME requires that field characterization and description of the mine entries are conducted. The purpose of such characterization is to establish in-depth knowledge and understanding of the physical and environmental hazards presented by the entries and to identify and quantify their associated socio-economic issues. This is important for the establishment of the site-specific issues of the abandoned mine entries. The knowledge of the problems of the mine entries generated through this process is also important for accurate scoring of the factors of the physical and environmental hazards of the mine entries. These factors were (i) the source of the hazards, (ii) the ways of exposure/pathways of the hazards, and (iii) the magnitude of the potential damage that the hazards may cause. Based on the scoring process, the environmental and physical risks of the mine entries as well as their socio-economic 
concerns were quantified. The magnitude (as was defined by the calculated scores) of the individual risks of the mine entries was then used to calculate the total hazard score, which was used by the expert system to classify the problems of the mine entries into four categories, namely; Negligible, Low, Moderate and High. The basic framework of the method that followed in the formulation of the production rules of the ES-RAME is shown in Figure 2.

Table 3. The general rules for developing decision tree in the expert system (ES)-Builder Shell [3].

\begin{tabular}{cc}
\hline Point & Rule \\
\hline 1 & The first node of the decision tree is the Universe of Discourse (UofD) \\
2 & The second node of the tree should be an Attribute that displays an "A" icon. \\
3 & Each Attribute to be tested in the ES should at least have two branching nodes \\
4 & The Value nodes are mostly the only type of branch nodes that are accepted by Attribute node. \\
5 & The Value node always represent the most correct response to an Attribute for a particular conclusion \\
6 & The Value nodes have two possible types of branch node; therefore, when further Attribute needs to \\
7 & be tested, a branch node of a Value will be another Attribute node \\
8 & The conclusion node must be a leaf node such that no branches are accepted from the conclusion node. \\
9 & Apart from the UofD (i.e., first node), about three data items can be added. \\
10 & Each Attribute, Value, and Conclusion node may consist of a detailed definition, a paragraph of help \\
notes, and an image to be displayed in the expert system.
\end{tabular}

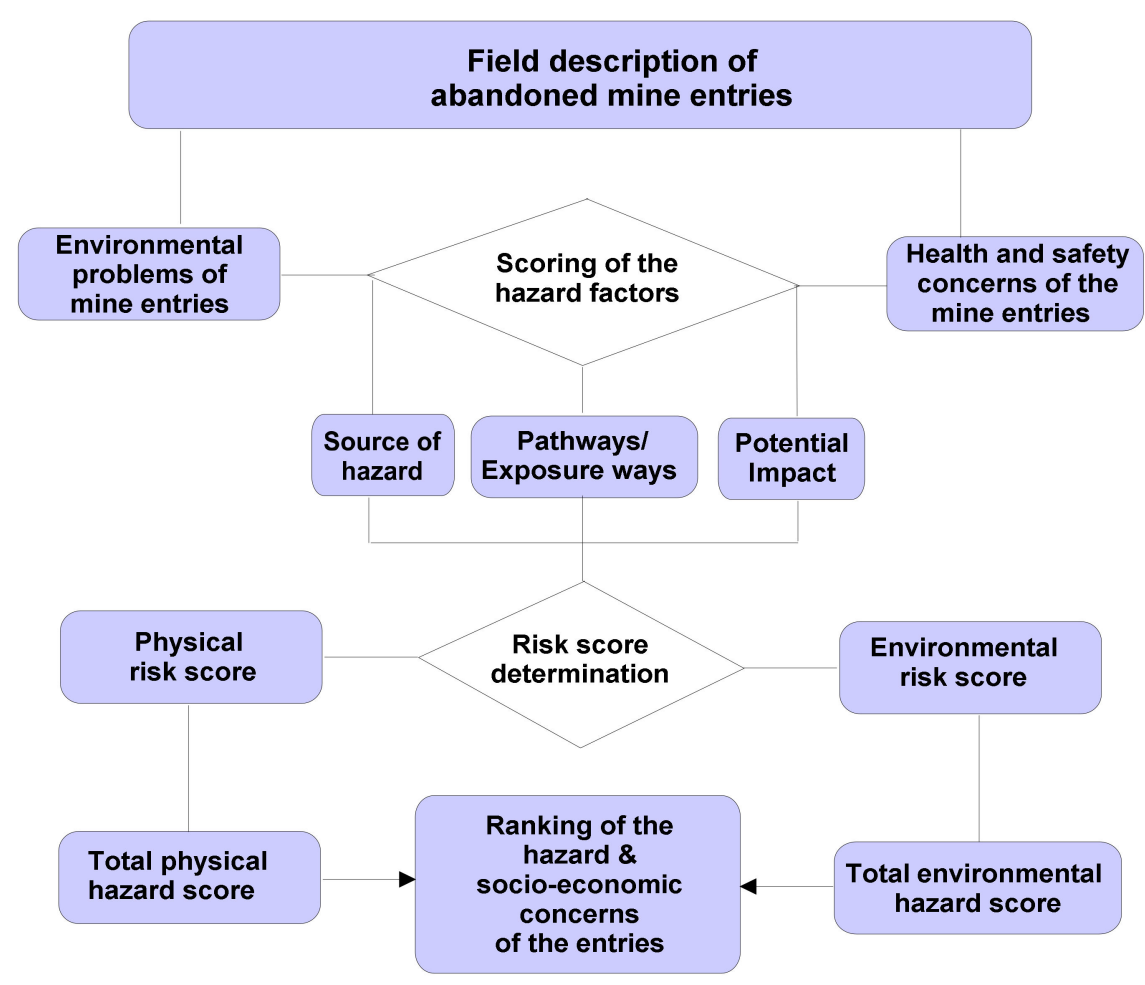

Figure 2. The framework of the method for ranking the problems of abandoned mine entries used to develop the production rules of the expert system for ranking problems of abandoned mine entries (ES-RAME).

\section{Results}

\subsection{The Production Rules of the ES-RAME}

The decision tree created for the ES-RAME assisted in coming up with nine conclusions, as shown in Figure 3. The conclusion statements given by the expert system are shown in Table 4 . The example of the production rules of this expert system made it possible that the environmental and physical hazards of the abandoned mine entries, together with their associated socio-economic concerns, could 
be ranked into four categories, which are High, Moderate, Low, and Negligible. This caused the decision tree developed for the expert system to be broadly divided into three branches, the first of which was responsible for the ranking of the physical hazards and social concerns of the mine entries, while the other assisted with the ranking of the environmental and economic impacts of the mine entries. The third branch of the decision tree was created to rank the mine entries in the situations where there was restricted access to the entries or the abandoned mine site at large.

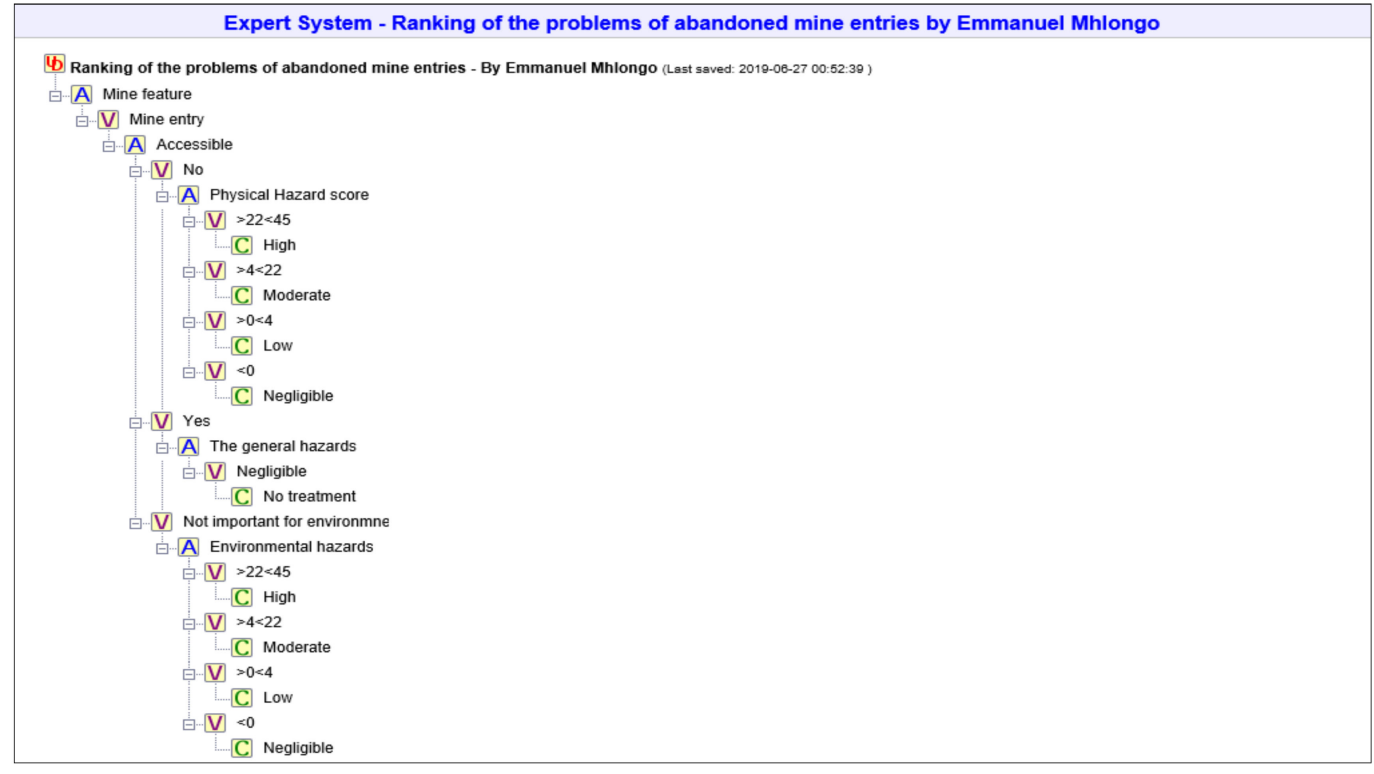

Figure 3. The structure of the decision tree for the ES-RAME.

Table 4. The decision table of the ES-RAME.

\begin{tabular}{|c|c|c|c|c|c|c|}
\hline Conclusion & $\mathrm{CF}$ & $\begin{array}{l}\text { Mine } \\
\text { Feature }\end{array}$ & Accessible & $\begin{array}{l}\text { Physical } \\
\text { Hazard } \\
\text { Score }\end{array}$ & $\begin{array}{c}\text { The General } \\
\text { Hazards }\end{array}$ & $\begin{array}{c}\text { Environmental } \\
\text { Hazards }\end{array}$ \\
\hline $\begin{array}{l}\text { High physical hazards } \\
\text { and social concerns }\end{array}$ & 1.00 & Mine entry & No & $>22,<45$ & - & - \\
\hline $\begin{array}{l}\text { Moderate physical } \\
\text { hazards and social } \\
\text { concerns }\end{array}$ & 1.00 & Mine entry & No & $>4,<22$ & - & - \\
\hline $\begin{array}{l}\text { Low physical hazards } \\
\text { and social concerns }\end{array}$ & 1.00 & Mine entry & No & $>0,<4$ & - & - \\
\hline $\begin{array}{l}\text { Negligible physical } \\
\text { hazards and social } \\
\text { concerns }\end{array}$ & 1.00 & Mine entry & No & $<0$ & & \\
\hline $\begin{array}{l}\text { No immediate } \\
\text { treatment needed }\end{array}$ & 1.00 & Mine entry & Yes & - & Negligible & - \\
\hline $\begin{array}{l}\text { High environmental } \\
\text { hazards and economic } \\
\text { concerns }\end{array}$ & 1.00 & Mine entry & $\begin{array}{l}\text { Not important for } \\
\text { environmental } \\
\text { hazards }\end{array}$ & - & - & $>22,<45$ \\
\hline $\begin{array}{l}\text { Moderate } \\
\text { environmental hazards } \\
\text { and economic concerns }\end{array}$ & 1.00 & Mine entry & $\begin{array}{l}\text { Not important for } \\
\text { environmental } \\
\text { hazards }\end{array}$ & - & - & $>4,<22$ \\
\hline $\begin{array}{l}\text { Low environmental } \\
\text { hazards and economic } \\
\text { concerns }\end{array}$ & 1.00 & Mine entry & $\begin{array}{l}\text { Not important for } \\
\text { environmental } \\
\text { hazards }\end{array}$ & - & - & $>0,<4$ \\
\hline $\begin{array}{l}\text { Negligible } \\
\text { environmental hazards } \\
\text { and economic concerns }\end{array}$ & 1.00 & Mine entry & $\begin{array}{l}\text { Not important for } \\
\text { environmental } \\
\text { hazards }\end{array}$ & - & - & $<0$ \\
\hline
\end{tabular}


In general, the developed production rules of the expert system are stored in the knowledge base of the system. The structure of the knowledge base of the ES-RAME with its production rules is shown in Appendix A. It is important to indicate that the production rules allow the user of the ES to arrive at a given conclusion, which is also displayed in the conclusion page of the expert system. An image that provides clues to the situation of the abandoned mine entry for which the conclusion is made is also displayed in the conclusion page of the expert system. An example of the conclusion pages of the ES-RAME is shown in Figure 4a,b.
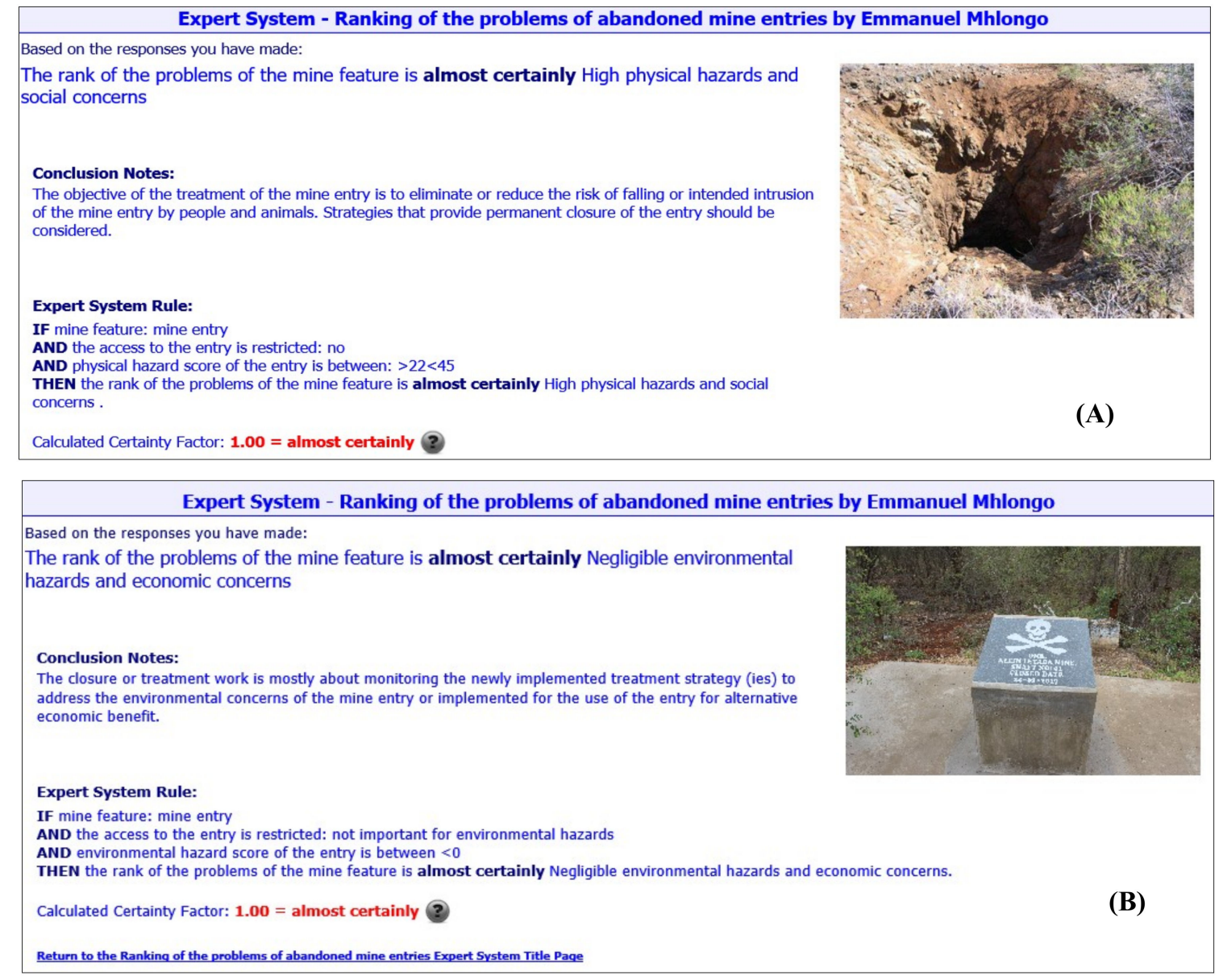

Figure 4. An illustration of the conclusion pages of the developed expert system for ranking of the problems of abandoned mine. (A) is the example of conclusion of the ES in high hazards mine entries and $(\mathbf{B})$ is the example of the conclusion in the negligible hazards of the mine entries.

In addition, the implementation of the method of ranking the problems of abandoned mine entries into the expert system shell made the system work in an interactive manner. In this, the user collected site-specific information about the mine entries and follows the guidance of the expert system in ranking hazards of the entries. This characteristics of the ES-RAME enabled easy use of the expert system in the manner that accommodated site-specific issues of the abandoned mine entries in the ranking process. They allowed the user to score the factors of the hazards or risks of the mine entries according to his/her field judgment of the situation on site. In this case, the user of the system was assisted by the expert system with the criteria for scoring the factors of the identified physical and environmental hazards of the mine entries. The ES-RAME also provided the description of the procedure for calculation of the total physical and environmental hazard scores of the abandoned mine entries. The instruction given by the ES-RAME on the process of the calculation of the environmental hazard scores is shown in Figure 5A, while that for calculation of the physical hazard scores is shown in Figure 5B. The general attributes of the ES-RAME are presented in Appendix B. 
Expert System - Ranking of the problems of abandoned mine entries by Emmanuel Mhlongo

Physical hazard score of the entry is between:

(For each identified physical risk, the source of the risk, exposure to the risk, and the potential impact of the risk to people and animals should be scored using the following criteria: Low (1.5-3.0), Moderate (3.5-5.0) and High (5.5-7.0). These scores should be used to calculate the individual risks (Pr) of the mine entries using the equation: $\operatorname{Pr}=Q s^{*} E^{*}(\mathrm{Ni}+\mathrm{Mi} / 2)$, Where; $Q s$ is the source of the risk, Ea is the exposure to the hazard, and $(\mathrm{Ni}+\mathrm{Mi} / 2)$ is the average of the safety risks (Ni) and associated health risks (Mi). The absent factor between Ni and Mi should be given a score of zero ( 0 ). The calculated Pr values of the identified risks of the should be used to calculate the total hazard score (HZtotal) of the shafts using the equation: HZtotal=(SumRi/NF)/n, Where; Ri is the sum of the scores of the physical risks, $n$ is the number of physical risks identified and $N F$ is the factor of 8 employed to reduce the magnitude of the scores.)

- $>\mathbf{4}<22$

Moderate physical hazards

- $\geq 22<45$

High physical hazards

$\cdot \geq 0<4$

Low physical hazards

- $\leq \mathbf{0}$

Negligible physical hazards

Decision History:

Mine feature:

The access to the entry is restricted:

Tip: Click on an attribute link above to return to that decision... Mine entry No

turn to the Ranking of the problems of abandoned mine entries Expert System Title Pao

(A)

Expert System - Ranking of the problems of abandoned mine entries by Emmanuel Mhlongo

Environmental hazard score of the entry is between

(For each identified environmental hazard of the mine entry, the source of the risk, pathway(s) and the impact it has on the environmental should be scored using the following criteria: Low (1.5-3.0), Moderate (3.5-5.0) and High (5.5-7.0). This scores should be used to calculate the individual environmental risk scores (Evr) of the entry using equation: Evr=Qi* $P^{*} R x$ Where; Qi is the source of the hazard, Pj is the pathway (given as 1 were the impact is on the aesthetic appearance of the landscape), and $R x$ is the magnitude of the risk. The determined Pr values should be used to calculate the total hazard score (Hztotal) of the mine entry using the following equation: HZtotal=(SumRi/NF)/n, Where; $n$ is the number of environmental risks identified and NF is the factor of 8 employed to reduce the magnitude of the scores. )

$\cdot \geq 22<45$

High environmental hazard

- $\geq \mathbf{4}<21$

Moderate environmental hazard

$\cdot \geq 0<4$

Low environmental hazards

- $\leq 0$

Negligible environmental hazards

Decision History:

Mine feature: $\quad$ Mine entry

The access to the entry is restricted: Not importent for environmental hazards

Tip: Click on an attribute link above to return to that decision...

Figure 5. An illustration of the instructions of the expert system concerning the hazard score determination. (A) is the instructions for determination of environmental hazard score and (B) is for the determination of physical hazard score.

Based on the determined physical and environmental hazard scores, the ES-RAME provide guidance on the ranking of the hazards. In each category of physical and/or environmental hazards, the ES-RAME was created to provide recommendation of the aim or objective of the mine entry treatment work. It is important to mention that the development of the decision tree and the production rules of the ES-RAME are based on the assumption that the environmental and physical hazards of abandoned mines are associated with the socio-economic concerns of these mines. This is because the environmental problems of the abandoned mines tend to result in the poor economic development of the area, while their physical hazards affect mostly the social well-being of the people residing around the abandoned mine sites. In view of these, the ES-RAME concluded by combining the physical hazards with social concerns of the mine entries and the environmental hazards with the economic issues of the host communities. 


\subsection{Application of the ES-RAME to the Mine Shafts of Giyani and Musina}

The developed rule-based ES-RAME was applied to the situation of abandoned mines in the areas of Giyani and Musina in the Limpopo Province of South Africa. The results of the ranking of the physical and environmental hazards of the mine entries in the study area are shown in Figure 6A,B. The ranking process demonstrated that the physical hazards of shafts in the two areas ranges from negligible to moderate levels. In this case, the physical hazard scores of the mine entries ranged from the minimum of 0.04 to the maximum of 15.09 (see Figure 6A). On the other hand, the environmental hazard scores ranged from 0.47 to 9.67 , which resulted in the classification of these hazards ranging from low to moderate levels (see Figure 6B).
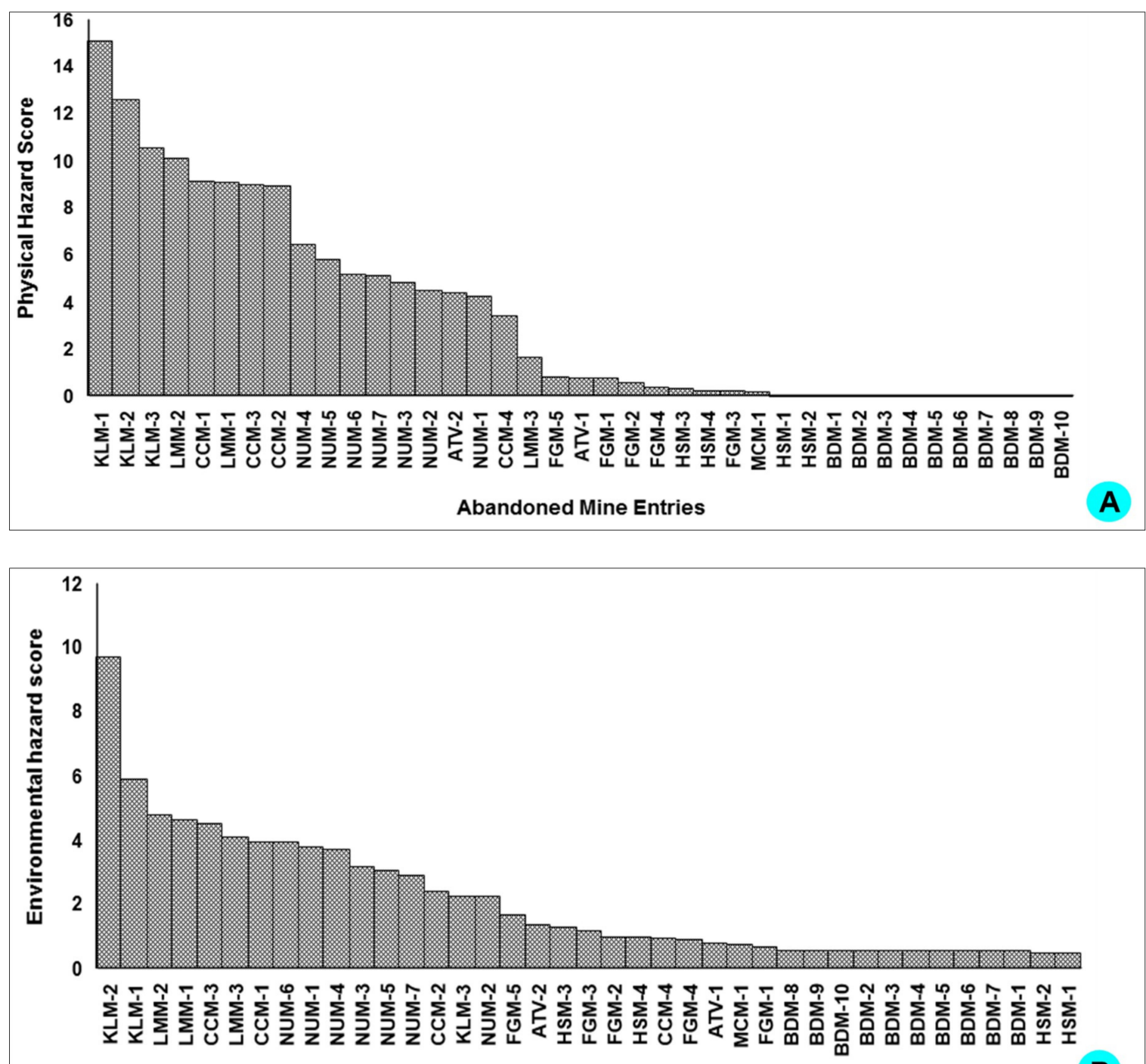

Abandoned Mine Entries

Figure 6. The physical (A) and environmental (B) hazards scores of the mine entries in the Giyani and Musina areas.

Based on the physical and environmental hazards score of the mine shafts, the ES-RAME classified the socio-economic concerns of the mine shafts in the Giyani and Musina areas so that they ranged from negligible to a moderate. In this case, the mine shafts that were recently treated or closed using both backfilling and installation of concrete plugs had negligible physical hazards while mine shafts that had minor ground movements were found to have low environmental problems. Most of the mine shafts that were treated/closed using concrete slabs and those that were found open were classified as 
having low and moderate socio-economic concerns, respectively. The mine shafts that had relatively elevated socio-economic concerns in the moderate category were the open openings that were in unstable grounds around Musina and the inclined shafts that were being entered by the illegal gold miners in the Giyani area. The guidance given by the expert system in terms of what should be the focus of the treatment work in these mine shafts as captured in the conclusion pages of the ES-RAME is shown in Table 5 .

Table 5. Ranking of problems of mine entries and the objectives of their treatment in the Giyani and Musina areas.

\begin{tabular}{ccc}
\hline $\begin{array}{c}\text { Problems of the } \\
\text { Mine Entries }\end{array}$ & $\begin{array}{c}\text { Conclusion-Ranking of the } \\
\text { Issues of the Mine Entries }\end{array}$ & Mine Shaft Treatment Objectives \\
\hline $\begin{array}{c}\text { Physical hazards and } \\
\text { social concerns }\end{array}$ & Negligible & $\begin{array}{c}\text { Monitoring of newly treated mine entries } \\
\text { Maintaining and repairing of deteriorating } \\
\text { treatment strategies }\end{array}$ \\
$\begin{array}{c}\text { Environmental hazards } \\
\text { and economic concerns }\end{array}$ & Moderate & $\begin{array}{c}\text { Closure of mine entries using temporary } \\
\text { structures }\end{array}$ \\
& Low & $\begin{array}{c}\text { Monitoring of newly treated mine entries } \\
\text { Maintaining and repairing of deteriorating } \\
\text { treatment strategies }\end{array}$ \\
\hline
\end{tabular}

\subsection{Implication for Treatment of the Mine Entries}

The analysis of the situation of the abandoned mine entries conducted in this research showed that these entries are generally characterized by noticeable levels of physical and environmental hazards. These hazards also have impact on the social and economic development of the host communities and/or the whole region where the abandoned mines are found. As a result, it is important that these concerns or problems of the abandoned mine entries be addressed through a progressive implementation of short- and long-term treatment strategies. Since there is generally gradational or overlapping contact between the categories of the problems of the mine entries, the implementation of the treatment strategies can be in a manner that overlaps, as shown in Figure 7.

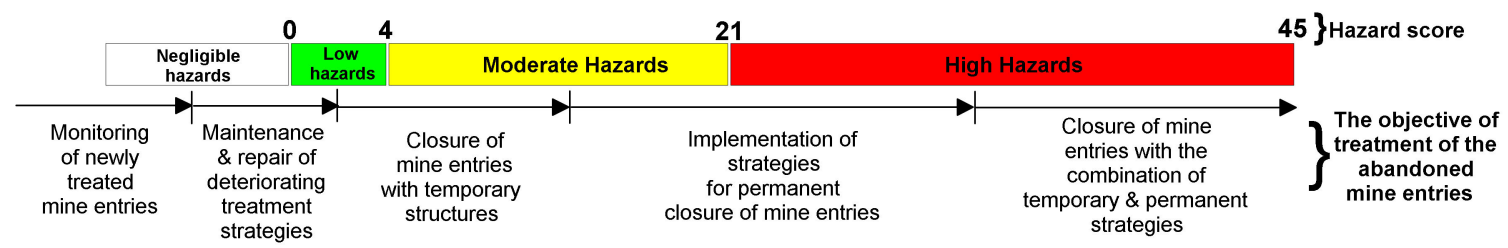

Figure 7. An illustration of the best approach for treatment of abandoned mine entries.

In this case, for the mine entries that have half score of the negligible category of the hazards to the half score in the category of low hazards, the treatment should focus on maintaining and repairing the failing or collapsing structures previously adopted in the treatment of the mine entries. Moving from low to moderate hazard categories, the treatment of the entries should mostly use structures that temporarily close the mine entries. The implementation of the strategies that provide permanent closure of the abandoned mine entries is to be considered in the case of mine entries that have hazard scores that are half way between the moderate and high categories. A graphical illustration of the recommended implementation of the treatment strategies for abandoned mine entries and the focus of the treatment efforts is shown in Figure 7.

\section{Discussion}

Abandoned mines are found in all countries and regions with long history of mining. The work of addressing the problems of these mines involves making several key decisions that mostly revolve around which features or sites are to be rehabilitated first and which strategies to use in the rehabilitation 
work. This is crucial, since the rehabilitation of these mines is mostly conducted with limited resources. Therefore, the accuracy of prioritization of the rehabilitation work coupled with the selection of the best approaches for rehabilitation of these mines have a potential to ensure that sustainable management of abandoned mine sites or features is achieved.

In view of this, different countries, individual researchers, and organizations have been making efforts to develop easy-to-use decision-making tools for rehabilitation of abandoned mines. In all attempts to develop such decision-making tools, the first tool that was developed in the form of an expert system was the tool known as the Abandoned Mines Hazard Ranking System-AMHAZ [30]. This tool used multi-criteria and pairwise comparison to rank the abandoned mine sites for rehabilitation. It did this based on the factors such as public safety and health, environmental problems, and socio-economic concerns [26].

In this research, the method for ranking the problems of abandoned mine entries was developed and incorporated into the web-based expert systems. The method ranks the problems of abandoned mine entries using the decision rules that are built into the knowledge base of the expert system shell. The incorporation of this expert system in the ES-Builder@2013 McGoo Software made it possible and simpler to create the web-link (i.e., URL) though which the ES-RAME can be accessed. Using this link, the ES-RAME can be published as a stand-alone expert system through sharing and following the link, or it can be published on the special website designed for such a purpose. The characteristics of the ES-RAME are shown in Table 6.

Table 6. The description of the developed expert system.

\begin{tabular}{cccc}
\hline Tittle of the ES & UofD & Notes & URL \\
\hline $\begin{array}{c}\text { Expert } \\
\text { of the problems of } \\
\text { abandoned mine } \\
\text { entries (ES-RAME) }\end{array}$ & $\begin{array}{c}\text { Rank of the } \\
\text { problem of } \\
\text { abandoned } \\
\text { mine entry }\end{array}$ & $\begin{array}{c}\text { This expert system will provide a } \\
\text { ranking of the problems of abandoned } \\
\text { mine entries so that appropriate } \\
\text { strategies for addressing such } \\
\text { problems can be identified }\end{array}$ & $\begin{array}{c}\text { http://www.mcgoo.com.au/ } \\
\text { esbuilder/viewer/viewES.php?es= } \\
\text { 008fb028150913e5e22ec4c9e936b304 }\end{array}$ \\
\hline
\end{tabular}

\section{Conclusions}

In this work, a web-based expert system for advising in the ranking of the problems of abandoned mine entries was developed. The system was comprised of the decision tree and production rules that assist in the ranking of the problems of abandoned mine entries. Its functionality was tested by applying it to the ranking of the problems of abandoned mine entries in the areas of Giyani and Musina, Limpopo Province of South Africa.

The implementation of the methodology for ranking the problems of abandoned mine entries into the expert system created using the web-based ES-Builder ${ }^{(} 2013$ McGoo Software made the developed ES-RAME easily available and accessible in and through the internet. The major advantage of implementing the abandoned mines ranking method in the rule-based expert system is that preliminary ranking can be easily conducted using fictitious or basic information about the situation of abandoned mine entries. Such preliminary or trial runs of the expert system can give the user a feel of and/or insight into the ranking process used by the system. It also provides the user with a clear understanding of the nature of information that is required for the actual ranking of the problems of the abandoned mine entries.

The ranking of the problems of abandoned mine entries using the ES-RAME also allows for the objectives of the treatment of the entries to be identified. This then ensures that the safety status of the abandoned mine entries is improved through the execution of appropriate strategies for dealing with their identified specific issues. These characteristics of the ES-RAME will go a long way in reducing the rehabilitation cost normally associated with use of unsuitable strategies for the problems of abandoned mines. The use of this system has the potential to assist or contribute to the sustainable management 
of the rehabilitation or treatment of abandoned mine entries in different parts of the world where they are found.

Author Contributions: This paper was written from the ongoing PhD work at the University of Vanda. S.E.M., F.A.-D., and A.K. contributed to the conceptualization of the work. Moreover, S.E.M. developed the expert system and wrote the first draft of this manuscript. F.A.-D. and A.K. supervised the development of the expert system and edited the manuscript.

Funding: This research did not receive any external funding. The fieldwork of the research was financially supported by the Office of the Vice Chancellor Academic (University of Venda) through the Capacity Development Grant (Grant Specific Number D027). The Article Processing Charges (APC) was funded by the Research and Publication Committee (RPC) of the University of Vanda.

Acknowledgments: The authors would like to acknowledge the assistance of C Muzerengi and GK Pindihama in conducting the field work part of this research. They are also grateful to the McGoo Software for making the ES-Builder Shell freely available online and for the constant guidance provided on different aspects of using the Shell. The authors also acknowledge the Dean (JO Odiyo) of the School of Environmental Sciences (University of Venda) for organizing the writing workshop that assisted in the reshaping of this paper.

Conflicts of Interest: The authors declare no conflict of interest.

\section{Appendix A}

\begin{tabular}{|c|c|c|c|}
\hline \# & Rule & Notes & Image \\
\hline 1 & $\begin{array}{l}\text { IF mine feature: mine entry } \\
\text { AND the access to the entry is restricted: no } \\
\text { AND physical hazard score of the entry is between: } \\
>22245 \\
\text { THEN the rank of the problems of the abandoned mine } \\
\text { entry is almost certainly (Cf=1.00) } \\
\text { High physical hazards and social concerns. }\end{array}$ & $\begin{array}{l}\text { The objective of the treatment of the mine entry is to eliminate or reduce the risk of falling or intended intrusion of the } \\
\text { mine entry by people and animals. Strategies that provide permanent closure of the entry should be considered. }\end{array}$ & \\
\hline 2 & $\begin{array}{l}\text { IF mine feature: mine entry } \\
\text { AND the access to the entry is restricted: no } \\
\text { AND physical hazard score of the entry is between: }>4<22 \\
\text { THEN the rank of the problems of the abandoned mine } \\
\text { entry is almost certainly (Cf }=1.00 \text { ) } \\
\text { Moderate physical hazards and social concerns. }\end{array}$ & $\begin{array}{l}\text { The objective of the treatment of the mine entry is that moderate efforts should be put on addressing the physical hazards } \\
\text { and social concerns of partially closed mine entries. This is when the abandoned mine entry has been first treated using } \\
\text { temporal structures which part of have been removed, destroyed or vandalized by the community. A permanent closure of } \\
\text { the shaft should be considered. }\end{array}$ & \\
\hline 3 & $\begin{array}{l}\text { IF mine feature: mine entry } \\
\text { AND the access to the entry is restricted: no } \\
\text { AND physical hazard score of the entry is between: }>0<4 \\
\text { THEN the rank of the problems of the abandoned mine } \\
\text { entry is almost certainly (Cf }=1.00 \text { ) } \\
\text { Low physical hazards and social concerns. }\end{array}$ & $\begin{array}{l}\text { Objective of treatment require that strategies that address the little physical hazards of the entries are required. This } \\
\text { involve the treatment of mine entries which the structure used to close them require some repair or maintenance. }\end{array}$ & \\
\hline 4 & $\begin{array}{l}\text { IF mine feature: mine entry } \\
\text { AND the access to the entry is restricted: no } \\
\text { AND physical hazard score of the entry is between: }<0 \\
\text { THEN the rank of the problems of the abandoned mine } \\
\text { entry is almost certainly (Cf }=1.00) \\
\text { Negligible physical hazard and social concerns. }\end{array}$ & The objective of the mine entry treatment is to monitor the performance of the newly installed treatment structure. & \\
\hline 5 & $\begin{array}{l}\text { IF mine feature: mine entry } \\
\text { AND the access to the entry is restricted: yes } \\
\text { AND the general hazards can be considered: negligible } \\
\text { THEN the rank of the problems of the abandoned mine } \\
\text { entry is almost certainly (CC }=1.00) \\
\text { No immediate treatment needed. }\end{array}$ & $\begin{array}{l}\text { The objective of treatment is that there in no required immediate treatment of the mine entry. The protection of the entry } \\
\text { from the public might be necessary to ensure the lack of exposure. }\end{array}$ & $\begin{array}{l}\text { DANGER } \\
\text { MINE SITE } \\
\text { NO TRESPASSING }\end{array}$ \\
\hline
\end{tabular}

\begin{tabular}{|c|c|c|c|}
\hline 6 & $\begin{array}{l}\text { IF mine feature: mine entry } \\
\text { AND the access to the entry is restricted: not important for } \\
\text { environmental hazards } \\
\text { AND environmental hazard score of the entry is between } \\
>22<45 \\
\text { THEN the rank of the problems of the abandoned mine } \\
\text { entry is almost certainly ( } \mathrm{Cf}=1.00 \text { ) } \\
\text { High environmental Hazard and economic concerns. }\end{array}$ & $\begin{array}{l}\text { The objective of the treatment of the entry involve elimination of environmental hazards which include excessive ground } \\
\text { movement and discharge of contaminated water by the entry. Permanent closure of the shaft should be considered. }\end{array}$ & \\
\hline 7 & $\begin{array}{l}\text { IF mine feature: mine entry } \\
\text { AND the access to the entry is restricted: not important for } \\
\text { environmental hazards } \\
\text { AND environmental hazard score of the entry is between } \\
>4<21 \\
\text { THEN the rank of the problems of the abandoned mine } \\
\text { entry is almost certainly (Cf }=1.00 \text { ) } \\
\text { Moderate environmental hazards and economic } \\
\text { concerns. }\end{array}$ & $\begin{array}{l}\text { The objective of the treatment of the mine entry is that moderate efforts should be given to addressing the manner } \\
\text { environmental problems such as the impact of the entry on the aesthetic appearance of the landscape, and the treatment } \\
\text { of water discharged by the entry. No threats of ground movement around the entry. The treatment strategy can be } \\
\text { permanent or temporal strategy. }\end{array}$ & \\
\hline 8 & $\begin{array}{l}\text { IF mine feature: mine entry } \\
\text { AND the access to the entry is restricted: not important for } \\
\text { environmental hazards } \\
\text { AND environmental hazard score of the entry is between } \\
>0<4 \\
\text { THEN the rank of the problems of the abandoned mine } \\
\text { entry is almost certainly ( }(\mathrm{f}=1.00) \\
\text { Low environmental hazard and economic concerns. }\end{array}$ & $\begin{array}{l}\text { The object of the treatment of the entry should focus on addressing the little environmental concerns identified to alleviate } \\
\text { the economic status of the abandoned mine shaft and its surroundings. }\end{array}$ & \\
\hline
\end{tabular}

Figure A1. The knowledge base rules of the ES-RAME. 


\section{Appendix B}

\begin{tabular}{|c|c|c|c|c|}
\hline \multicolumn{5}{|c|}{ Expert System - Ranking of the problems of abandoned mine entries by Emmanuel Mhlongo } \\
\hline \multicolumn{5}{|c|}{ List of Attributes - This expert system uses Simple Certainty Factors applied by the creator of the system. } \\
\hline Node & Text & Values & Notes & Image \\
\hline Mine feature & Mine feature: & $\begin{array}{l}\text { Mine entry ( } \mathrm{Cf}=1.00) \\
\text { [This includes all openings that } \\
\text { connect with the abandoned } \\
\text { underground mine workings. } \\
\text { They may be vertical or inclined } \\
\text { shafts, edits or dedines, tunnels } \\
\text { and even sinkholes.] }\end{array}$ & & \\
\hline Accessible & $\begin{array}{l}\text { The access to the } \\
\text { entry is } \\
\text { restricted: }\end{array}$ & $\begin{array}{l}\text { Yes }(\mathrm{Cf}=1.00) \\
\text { [The mine entry can not be } \\
\text { easily accessed by people and } \\
\text { animals ] } \\
\text { No }(\mathrm{Cf}=1.00) \\
\text { [The entry and/or the whole of } \\
\text { the abandoned mine site is open } \\
\text { to the public. ] } \\
\text { Not important for } \\
\text { environmental hazards } \\
\text { (Cf=1.00) } \\
\text { [The environmental problems of } \\
\text { the abandoned mine entry are of } \\
\text { concern in this case. ] }\end{array}$ & $\begin{array}{l}\text { This refer to the exposure of the mine entry to the members of the public. Note; the mine entry } \\
\text { might be treated/closed or not. }\end{array}$ & \\
\hline
\end{tabular}

\begin{tabular}{|c|c|c|c|}
\hline $\begin{array}{l}\text { Physical } \\
\text { Hazard score }\end{array}$ & $\begin{array}{l}\text { Physical hazard } \\
\text { score of the } \\
\text { entry is between: }\end{array}$ & $\begin{array}{l}>4<22(\mathrm{Cf}=1.00) \\
{[\text { Moderate physical hazards] }} \\
>22<45(\mathrm{Cf}=1.00) \\
\text { [High physical hazards] } \\
>0<4(\mathrm{Cf}=1.00) \\
{[\text { Low physical hazards] }} \\
<0(\mathrm{Cf}=1.00) \\
\text { [Negligible physical hazards ] }\end{array}$ & 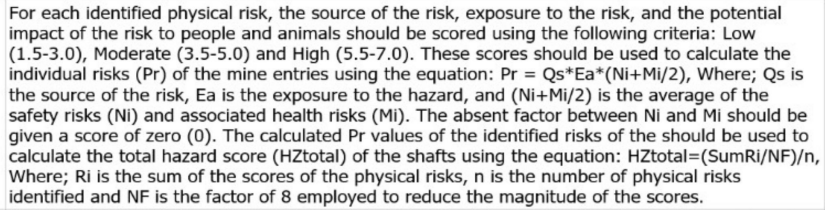 \\
\hline $\begin{array}{l}\text { The general } \\
\text { hazards }\end{array}$ & $\begin{array}{l}\text { The general } \\
\text { hazards can be } \\
\text { considered: }\end{array}$ & $\begin{array}{l}\text { Negligible }(\mathrm{Cf}=1.00) \\
\text { [This because there is no } \\
\text { exposure to the hazards of the } \\
\text { abandoned mine entry] }\end{array}$ & $\begin{array}{l}\text { The risks of the mine entry are extremely reduced by prevention of access. These is a mine entry } \\
\text { in a well fenced and protected abandoned mine site. Mostly the entry is protected because there } \\
\text { is a hope for reuse of the mine entry for future mining activities. }\end{array}$ \\
\hline $\begin{array}{l}\text { Environmental } \\
\text { hazards }\end{array}$ & $\begin{array}{l}\text { Environmental } \\
\text { hazard score of } \\
\text { the entry is } \\
\text { between }\end{array}$ & $\begin{array}{l}>22<45(\mathrm{Cf}=1.00) \\
{[\text { Hiligh environmental hazard] }} \\
>4<21(\mathrm{Cf}=1.00) \\
{[\text { Moderate environmental }} \\
\text { hazard }] \\
>0<4(\mathrm{Cf}=1.00) \\
{[\text { Low environmental hazards ] }} \\
<0(\mathrm{Cf}=1.00) \\
{[\text { Negligible environmental }} \\
\text { hazards ] }\end{array}$ & $\begin{array}{l}\text { For each identified environmental hazard of the mine entry, the source of the risk, pathway(s) } \\
\text { and the impact it has on the environmental should be scored using the following criteria: Low } \\
(1.5-3.0) \text {, Moderate (3.5-5.0) and High (5.5-7.0).This scores should be used to calculate the } \\
\text { individual environmental risk scores (Evr) of the entry using equation: Evr=Qi*Pj*Rx Where; Qi is } \\
\text { the source of the hazard, } \mathrm{Pj} \text { is the pathway (given as } 1 \text { were the impact is on the aesthetic } \\
\text { appearance of the landscape), and Rx is the magnitude of the risk. The determined Pr values } \\
\text { should be used to calculate the total hazard score (HZtotal) of the mine entry using the following } \\
\text { equation: HZtotal=(SumRi/NF)/n, Where; } n \text { is the number of environmental risks identified and } \\
\text { NF is the factor of } 8 \text { employed to reduce the magnitude of the scores. }\end{array}$ \\
\hline
\end{tabular}

Figure A2. The list of the attributes of the ES-RAME.

\section{References}

1. Burhan, A.M. Developing an expert system for the investigation of construction failure causes by using es builder program. Appl. Res. J. 2016, 2, 43-49.

2. Gunawan, E.P.; Wardoyo, R. An expert system using certainty factor for determining insomnia acupoint. Indones. J. Comput. Cybern. Syst. 2018, 12, 119-128. [CrossRef]

3. Duana, Y.; Edwards, J.S.; Xu, M.X. Web-based expert systems: Benefits and challenges. Inf. Manag. 2005, 42, 799-811. [CrossRef]

4. Jain, R. Expert systems: A management perspective. Vikalpa 1989, 14, 17-28. [CrossRef]

5. Lucas, P. Expert Systems; Encyclopedia of Life Support Systems (EOLSS): Abu Dhabi, UAE, 2004; p. 9.

6. Salim, M.D.; Villavicencio, A.; Timmerman, M.A. A Method for evaluating expert system shells for classroom instruction. J. Ind. Technol. 2003, 19, 1-11.

7. Eldrandaly, K. An Intelligent MCDM approach for selecting the suitable expert system building tool. Int. Arab J. Inf. Technol. 2007, 4, 365-372.

8. Zuhra, F.T.; Arai, A.A.; Tuni, M.A. An implementation of expert system for orthopedic patient diagnosis. Quaid E Awam Univ. Res. J. Eng. Sci. Technol. 2016, 15, 40-45.

9. Matthew, O.; Buckley, K.; Garvey, M.; Moreton, R. Multi-tenant database framework validation and implementation into an expert system. Int. J. Adv. Stud. Comput. Sci. Eng. 2016, 5, 13-21.

10. Hogo, M.A.; Fouad, K.; Mousa, F. Web-Based expert system for civil service regulations: RCSES. Int. J. Comput. Sci. Inf. Secur. 2009, 6, 7-16.

11. Grove, R. Internet-based expert systems. Expert Syst. 2000, 17, 129-135. [CrossRef] 
12. Mhlongo, S.E.; Amponsah-Dacosta, F. A review of problems and solutions of abandoned mines in South Africa. Int. J. Min. Reclam. Environ. 2016, 30, 279-294. [CrossRef]

13. Auditor-General South Africa. Report of the Auditor-General to Parliament on a Performance Audit of the Minerals and Energy; Auditing to Build Public Confidence; AGSA: Pretoria, South Africa, October 2009.

14. Mhlongo, S.E.; Amponsah-Dacosta, F.; Kadyamatimba, A. Development and use of hazard ranking system for abandoned mine entries: A case study of the mine shafts in Giyani and Musina Areas of South Africa. Cogent Eng. 2018, 5, 1-19. [CrossRef]

15. Mhlongo, S.E.; Amponsah-Dacosta, F.; Muzerengi, C.; Gitari, W.M.; Momoh, A. The impact of artisanal mining on rehabilitation efforts of abandoned mine shafts in Sutherland goldfield, South Africa. Jàmbá J. Disaster Risk Stud. 2019, a688. [CrossRef] [PubMed]

16. Mhlongo, S.E.; Amponsah-Dacosta, F.; Kadyamatimba, A. Appraisal of strategies for treatment of abandoned mine shafts in the Giyani and Musina areas of Limpopo Province of South Africa. In Proceedings of the 12th International Conference on Mine Closure, Leipzig, Germany, 3-7 September 2018; Drebenstedt, C., von Bismarck, F., Fourie, A., Tibbett, M., Eds.; Technical University Bergakademie Freiberg: Freiberg, Germany, 2018; pp. 414-424.

17. Pioneer Technical Services Inc. Abandoned Hard Rock Mine Priority Sites 1994 Summary Report. In Montana Department of State Lands Abandoned Mine Reclamation Bureau; Engineering Services Agreement DSL-AMRB No. 94-006; Pioneer Technical Services Inc.: Butte, MT, USA, 1994; p. 148.

18. Jordan, G.; Abdaal, A. Decision support methods for the environmental assessment of contamination at mining sites. Environ. Monit. Assess. 2013, 185, 7809-7832. [CrossRef] [PubMed]

19. Day, S.J.; Harpley, D.P. Survey of closed and abandoned mines in British Columbia for acid rock drainage I: Regional perspective. The Technical and Research Committee on Reclamation. In Proceedings of the 16th Annual British Columbia Mine Reclamation Symposium, Smithers, BC, USA, 15-18 June 1992; pp. $152-161$.

20. Power, B.A.; Tinholt, M.J.; Hill, R.A.; Fikart, A.; Wilson, R.M.; Stewart, G.G.; Sinnett, G.; Runnells, J.L. A risk ranking methodology for prioritizing historic, potentially contaminated mine sites in British Columbia. Integr. Environ. Assess. Manag. 2009, 6, 145-154. [CrossRef] [PubMed]

21. Tremblay, G.A.; Hogan, C.M. Approaches for the Remediation of Abandoned Mines and NOAMI. Proceedings of Symposium 2008 Rouyn-Noranda, Mines and the Environment, Rouyn-Noranda, QC, Canada, 2-5 November 2008; pp. 1-12.

22. Luodes, N.M. Inventory of closed and abandoned mines methods for performing the inventory and for risk classification with diverse data availability levels. Bachelor' Thesis, Mikkeli University of Applied Sciences, Mikkeli, Finland, 2013.

23. Geological Survey of Ireland and the Environmental Protection Agency. Appendix 1: Historic Mine Site Scoring System (HMS-SS), A Project to Categorize Contamination Sources from Mine Waste at Historic Mine Sites; Geological Survey of Ireland and the Environmental Protection Agency: Dublin, Ireland, 2009; p. 51.

24. PGeo, E.G.S.; Gallagher, V.; Mhairtín, F.N.; Brogan, J.; Lally, P.; PGeo, E.E.D.; PGeo, E.L.F. Geochemical Characterization and Environmental Matters Historic Mine Sites-Inventory and Risk Classification: A Joint Study Carried out by the Environmental Protection Agency and the Geological Survey of Ireland; The Geological Survey of Ireland: Dublin, Ireland, 2009; Volume I, p. 170.

25. Bolger, P.M.; Duszak, Z.; Koczkodaj,W.W.; Mackasy, W.O. Big problems/small problems? Applying 'first things first' principle towards establishing a management system (AMHAZ) for prioritizing abandoned mine hazards. In Proceedings of the Sudbury 95, Conference on Mining and Environment, Sudbury, ON, Canada, 28 May-1 June 1995; pp. 339-348.

26. Mackasey, W.O. Abandoned Mines in Canada; WOM Geological Associates Inc.: Sudbury, ON, Canada, 2000; p. 14.

27. Kubit, O.E.; Pluhar, C.J.; De Graff, J.V. A model for prioritizing sites and reclamation methods at abandoned mines. Environ. Earth Sci. 2015, 73, 7915-7931. [CrossRef]

28. Chaumba, J.B.; Mundalamo, H.R.; Ogola, J.S.; Cox, J.A.; Fleisher, C.J. Petrography, sulfide mineral chemistry, and sulfur isotope evidence for a hydrothermal imprint on Musina copper deposits, Limpopo Province, South Africa: Evidence for a breccia pipe origin? J. Afr. Earth Sci. 2016, 120, 142-159. [CrossRef] 
29. Parnham, D. Creating shareholder value in South Africa and Canada, Unlocking value in the Limpopo Provence; Giyani Gold Corp: Oakville, ON, Canada, 2015; p. 21.

30. Duszak, Z.; Koczkodaj, W.W.; Mackasey, W.O. Towards better abandoned mine hazard prioritization an expert system. In Proceedings of the 10th National Meeting of ASSMR, Spokane, WA, USA, 16-19 May 1994; pp. 577-590.

(C) 2019 by the authors. Licensee MDPI, Basel, Switzerland. This article is an open access article distributed under the terms and conditions of the Creative Commons Attribution (CC BY) license (http://creativecommons.org/licenses/by/4.0/). 